\title{
THE FUNCTION AND PURPOSE OF AIRCRAFT ACCIDENT INVESTIGATION ACCORDING TO THE INTERNATIONAL AIR LAW
}

\author{
Atip Latipulhayat* \\ The Indonesian Centre for Air and Space Law (ICASL) \\ Faculty of Law Universitas Padjadjaran \\ Jalan Imam Bonjol Nomor 21, Bandung, Jawa Barat
}

\begin{abstract}
The main objective of an aircraft accident investigation is to find out the most probable causes of such accident. This represents a technical investigation in nature. At the practical level, however, this report is often used as legal evidence before the court. This paper argues that the main purpose of an aircraft acccident investigation is technical in nature and judicial investigation is carried out when the technical investigation found elements of crime that has been alleged as the most probable cause of the accident.
\end{abstract}

Keywords: aircraft, accident, investigation.

\section{Intisari}

Menurut Konvensi Chicago 1944, tujuan utama suatu investigasi kecelakaan pesawat udara adalah untuk menemukan penyebab terjadinya kecelakaan tersebut. Jadi, investigasi ini bersifat teknis. Namun, laporan investigasi ini seringkali dijadikan alat bukti di pengadilan khususnya apabila faktor kesalahan manusia dianggap sebagai penyebab utama terjadinya kecelakaan tersebut. Investigasi teknis berubah menjadi investigasi yuridis. Tulisan ini berpendapat bahwa hakikat investigasi kecelakaan pesawat udara adalah bersifat teknis dan investigasi yuridis hanya akan dilakukan apabila laporan investigasi teknis menunjukkan adanya elemen kriminal.

Kata Kunci: pesawat udara, kecelakaan, investigasi.

\section{Pokok Muatan}

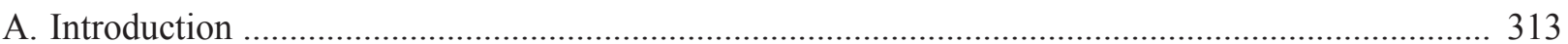

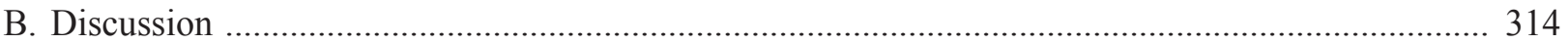

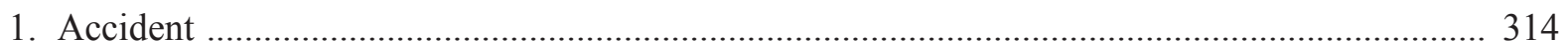

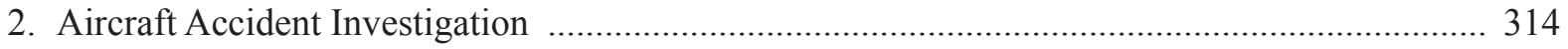

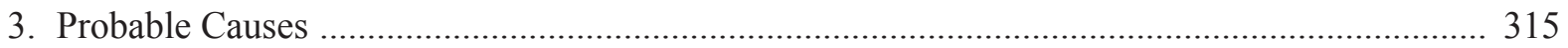

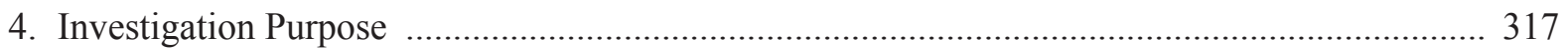

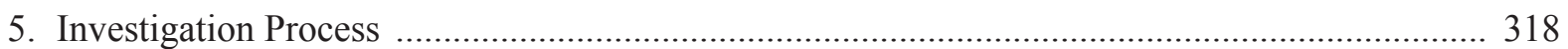

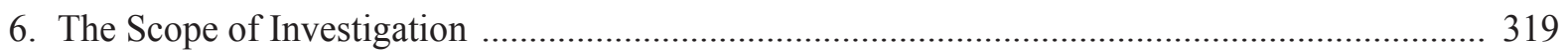

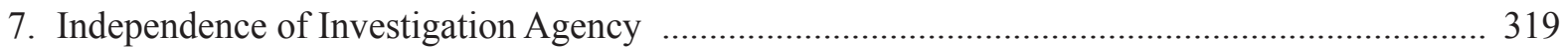

8. Aircraft Accident Investigation: Technical or Juridical? ......................................................... 320

9. Aircraft Accident Investigation System in Indonesia ............................................................... 322

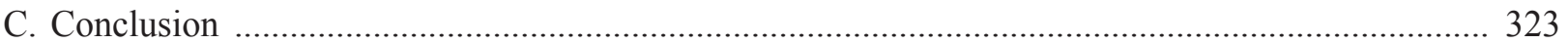




\section{A. Introduction}

Safety is the basic element in Air transportation. There are so many regulations that related with aviation that are made to fulfill the high safety standard. Article 44 Chicago convention (hereinafter mention as Chicago convention) explains that the main purpose ICAO (International Civil Aviation Organization) is to insure the safe and orderly growth of international civil aviation throughout world.

Literally, safety is freedom from danger or risks. ${ }^{1}$ However, in fact there is no guarantee that a flight will free from danger or accident. According to this fact, the expert of Air law such as Wassenbergh explain that the aviation safety as no (avoidable) accidents or few accident as possible. ${ }^{2}$ In the next progress, the ICAO Air navigation commission defines that aviation safety as the sate of freedom from unacceptable risk of injury to persons or damage to aircraft and property. ${ }^{3}$

Safety standard is reached by determine technical parameter and safety regulation. The important role of safety regulation is to strengthen and ensure the technical safety can be applied correctly and responsibly by everyone who are involved in the aviation activities. Therefore, actually air transportation is the safest mass transportation. The technical and regulation aspect are made very completely and carefully. Raison d'etre from all aspects is to create the transportation that has a high safety and security level.

The resposibility consecution to fulfill the high safety standard, it must be conducted an investigation to find out the aircraft accident cause in order to prevent the same accident and it also as input to create a good system and technology which are more sophisticated to guarantee the flight safety. ${ }^{4}$ Article 26 Chicago convention oblige each country to conduct an investigation when aircraft accident is occured. ${ }^{5}$

Air transportation is rare occur if it is compared with ground transportation. However, air accident is very catastrophic, it is always take many victims. The same thing is occur in Indonesia, the Fall of Sukhoi Superjet 100 at Salak Mountain on 2012 is one of catastrophic aircraft accident in Indonesia. The fall of Air Asia QZ8501 at Karimata bay in the beginning of 2015 that killed 162 passengers include the aircraft crews is added the list of catastrophic accident in Indonesia's aviation.

Different with other accident that occur in the others transportation, the aircraft accident always get more attention not only from the country that the accident happen but also International citizen, for example the report of Asiana Airlines that fail in landing at San Francisco (July 2013). Likewise the fall of Sukhoi Superjet 100 that is doing joy flight at Gunung Salak - Bogor (March 2012), Lion Air that fail in landing at Bali (April 2013). The most sensational is continues accident in 2104 such as the fall of MH 370 that no one know the location until today and the fall of MH 017 at Ukraine.

Some speculations are popping up after the accident, from the Engine failure until the pilot negligence. Moreover, there is any speculation in the criminal and terrorism case. All the speculations are legal. Furthermore, the validation will be confirmed by investigation. The important question is: What is the main purpose of the investigation in case with the aircraft accident? The main purpose from the investigation is to find out the probable cause why the accident happens. Stephen Dempsey says: the cause of an aviation catastrophe consists of the omissions, events, conditions, or a combination

Lesley Brown, 1993, The New Shorter Oxford English Dictionary Vol. 2, Clarendon Press, Oxford, p. 2666.

Henri Wassenbergh, "Safety in Air Transportation and Market Entry", Journal of Air and Space Law, Vol. 23, No. 2, 1998, p. 83.

ICAO Working Paper AN-WP/7699, 11 December, 2001, paragraph 22. See C.O. Miller, "State of the Art in Air Safety", Journal of Air Law and Commerce, Vol. 34, 1957, pp. 343, 347.

Paul Stephen Dempsey, "Independence of Aviation Safety Investigation Authorities: Keeping the Foxes from the Henhouse", Journal of Air Law and Commerce, Vol. 75, No. 2, 2010, p. 223.

Article 26 Chicago Convention 1944 states as follows: "In the event of an accident to an aircraft of a contracting State occurring in the territory of another contracting State, and involving death or serious injury, or indicating serious technical defect in the aircraft or air navigation facilities, the State in which the accident occurs will institute an inquiry in the circumstances of the accident, in accordance, so far as its laws permit, with the procedure which may be recommended by the International Civil Aviation Organization". 
thereof which led to the accidentor incident. ${ }^{6}$ So, the orientation prefer to the technical investigation. However, in the fact the investigation can change into judicial investigation in order to know the person who responsible from the accident.

According to the explanation above, there are three main problems that will be discussed in this paper that are: First, what is the function and purpose of aircraft accident investigation according to the international air law? Second, how about relation and interaction between technical investigation and judicial investigation in aircraft accident investigation? Third, how the form and mechanism aircraft accident investigation in Indonesia that is proper with Indonesia's law system and comply with international air law?

\section{B. Discussion}

\section{Accident}

To make sure the purpose of aircraft accident investigation, firstly it is need to explain the definition and restriction of accident. Moreover, the word of accident is also used incident terminology. Based on the Annex 13 Chicago convention (hereinafter is mentioned Annex 13), the term of accident refer to the event that are related to the operating of air plane since a person boarding until they take off from the air plane in which in this flight occur an event that make the person have severe injury in the air plane or because of directly contact with the part of the airplane or because of the engine explosion. Including the accident that is caused by the damage of plane structure that effect to the engine and the accident that is caused by the missing of plane or the plane cannot be detected the location. ${ }^{7}$
Meanwhile, the meaning of accident in the term of incident (in Bahasa Indonesia it change into "insiden") is an occurrence, other than an accident, associated with the operation of an aircraft which affects or could affect the safety of operation". 8 Based on the definition before the definition of accident in the term of incident is the event that exclude from the accident category, but this event can be influential to the aircraft safety. In this definition, so incident is not included to the event that needs an investigation as required by Annex 13. Even if the investigation is conducted it will be a preventive investigation in the meaning of to prevent the incident not to lead into accident.

The basic differential between accident and incident is, firstly an accident is caused victim who got serious injury even death, ${ }^{9}$ while the incident is an event that will not caused victim. ${ }^{10}$ This thing is confirmed by expert opinion such as Kjellen, he says "a sequence of logically and chronologically related deviating events involving and accident that results in injury to personnel or damage to the environment or material assets". ${ }^{11}$ So, the important thing that makes an event will be qualified as accident if it is will the event is caused serious injury or substantial plane damage. ${ }^{12}$ The difference is used as the basis and reason to conduct investigation to the event that is categorized as accident that has main purpose to prevent the same thing will be occur again.

\section{Aircraft Accident Investigation}

Aircraft accident investigation is still become the most important and determined thing to collect information and evidences that become the cause of the accident. The evidences will be an accurate data and information then it will be used for prevent the

\footnotetext{
Dempsey, Op.cit., p. 226. See Francis Schubert,"Legal Barriers to a Safety Culture in Aviation", Annals of Air and Space Law, Vol. 29, Issue 1, 2004, pp. 19 and 25. See Annex 13 Chicago Convention: "The sole objective of the investigation of an accident or incident shall be the prevention of accidents and incidents. It is not the purpose of this activity to apportion blame or liability". Also see Col. Luis E.Cortiz \& Griselda Capaldo,'Can Justice Use Technical and Personal Information Obtained Through Aircraft Accident Investigations?", Journal of Air Law and Commerce, Vol. 65, No. 2, 2000, pp. 263, 272-77. See also, Paul Stephen Dempsey, 2008, Public International Air Law, McGill University, Montreal, pp. 158-60.

See Chapter 1 Annex 13 Chicago Convention on International Civil Aviation 1944

Ibid.

Ibid. The difference between an accident and a serious incident lies only in the result.

Ibid. An incident involving circumstances indicating that an accident nearly occurred.

U. Kjellen and T.J. Larsson, "Investigating Accidents and Reducing Risks - A Dynamic Approach", Journal of Occupational Accidents, Vol. 3, Issue 2, 1981, p. 129.

12 Alexander T Wells and Clarence C. Rodrigues, 2003, Commercial Aviation Safety, McGraw-Hill, New York, p. 61.
} 
same way accident. Chicago convention explains about the definition of accident investigation as follows: ${ }^{13}$ A process conducted for the purpose of accident prevention which includes the gathering and analysis of information, the drawing of conclusions, including the determination of causes and, when appropriate, the making of safety recommendations.

The collecting information activity and analysis process is the most important thing in the investigation activity. The result that want to be gained is there will be founded a possibility that cause of the accident occur which in legal case is known as cause or probable cause.

The cause terminology first time was used in United State in the American Air Commerce Act of 1926 which is one of the rules is ruling about the duty of the Department of Commerce to conduct investigation, record, and publication to the public about the cause of accidents. After the Law was amended, it is used probable cause terminology eight year later. In 1958, United State establishes Federal Aviation Administration (FAA) and Civil Aeronautics Board (CAB). The $\mathrm{CAB}$ organization has a duty to conduct an aircraft accident investigation and give a report about the facts, conditions, and other things that related to the accident which is can be the probable cause. In 1974, National Transportation Safety Board (NTSB) was established, the organization has a specific duty to conduct investigation and find out the probable cause of aircraft accident. ${ }^{14}$ According to the explanation before it can be concluded that aircraft accident investigation is an activity to collect and analyze data and information that are related with the factors which become the probable cause.

\section{Probable Causes}

Probable cause terminology becomes the key word in the aircraft accident investigation. If the investigation finds the probable cause it will direct to the preventive action quickly and accurately. This investigation characteristic is distance to find the guilty party, but prefer to the action to prevent the accident effectively. Therefore, cooperation between all parties that are related to the accident is very needed to find the true causes of the accident. The short-term purpose of investigation that only to find the guilty party will be damage the long-term purpose of aircraft accident investigation which for to prevent the same way accident. ${ }^{15}$

Probable cause terminology that becomes the key word from aircraft accident investigation in the academic field still become debate and difference interpretation. There are some terminologies that is used to show the development of this investigation such as cause, probable cause, probable cause and proximate cause. The director of American Civil Aviation Authority Air Safety Board, Jerry Lederer explains the definition of probable cause as follow; "We, therefore, Endeavour to state how the accident happened and why. The 'couse' is our conclusion expressed in terms of probable cause and contributing factors. It has been our endeavour to stick to a practical pattern which establishes the proximate causes as the probable cause and sets up the underlying or more remote causes as contributing factors".

The Lederer's opinion gives a short and accurate explanation that the definition of probable cause is represented by word why, why an accident is occurred. However, the interesting thing is Lederer also give a similar terminology I.E proximate cause. Even though, the both of terminologies are considered as Law terminology, but proximate cause terminology is usual used in the court while the probable cause is technical terminology that usual used in the accident report. ${ }^{17}$

There some explanations that is tried to

\footnotetext{
13 Chapter I Annex 13 Chicago Convention on International Civil Aviation 1944.

14 " [...] to investigate or cause to be investigated (in such details it shall prescribe), and determine the facts, conditions, and circumstances and the cause or probable cause or causes of accidents". See also Michaelides Mateou and Andreas Mateou, 2010, Flying in the Face of Criminalization: The Safety Implications of Prosecuting Aviation Professionals for Accidents, Ashgate, UK, p. 39.

15 Ibid.

16 As quoted by Mateou and Mateou, Loc.cit.

17 Ibid.
} 
be applied to terminology of probable cause and proximate cause that is direct result, natural consequence, reasonable anticipation, reasonable inquiry, reasonable probable, foresee ability. The diversity explanations make the investigators have a difficulty to decide certainly cause of this accident. Deciding the accident cause is the purpose of aircraft accident investigation, but there is no standard definition which can help the investigation so it can give a tested conclusion.

In practice, the investigators use some terminologies that have similar meaning with the real meaning of cause or probable cause. There are some terminologies like causal factors, determining factors, contributing factors, safety problems, active failures and latent conditions. ${ }^{18}$ The terminologies actually are directed into same meaning that is the factors or elements which become the accident cause. In this case Hopkins confirms if there is finding a relation between cause and effect it is need to be formulated by this sentence:

"If we said but for the first time, so the second time will not occur". ${ }^{19}$ For the same purpose Leprad says that "when you said that $\mathrm{X}$ is the cause of $\mathrm{Y}$ accident, so actually you said that the $\mathrm{X}$ event is the requirement to be occurring Y event". ${ }^{20}$ Nonetheless, according to the Kletz it will better to avoid in using cause terms in the accident investigation. Kletz suggest to use a term that prefer to the attempt in preventing the accident, because in using cause terms it will make the investigator accuse one of parties that responsibility to this accident indirectly. This case should be avoided in the aircraft accident investigation, Kletz says. ${ }^{21}$

To find out the problem solution from this problem, ICAO gives a rule that is ruling about an accident investigation report must be contain the list of evidences and the accident cause factors. The list of factors that cause accident must include the immediate and deeper systemic causes. The definition of causes is the event that makes a victim or damage by their self or combination with others. In some countries they make the list of accident cause chronologically and there are not directed to the priority scale from the factors causes. Meanwhile, there are any countries that make a list by scale system priority to be classified into primary causes or contributing causes. ${ }^{22}$

Even though, ICAO gives guidance but, there still so many diversities in conducting aircraft accident investigation in each country. In some cases the investigation report is probable cause it is indirectly directed to the certain parties as the accident causes. Related with this case Frenwick and McKellar state that: ${ }^{23}$

There seem to be a growing consensus that to include 'probable cause' in the report is outdated. Many believe that emphasizing a single cause may even be detrimental to gaining a complete understanding of what happened and that nonpejorative language is more beneficial to the making of a complete safety report.

In the practical definition of probable cause is understood into 2 (two) meanings as technical and juridical terminology. In the technical meaning probable cause refer to the possibility and not direct to blame to the one party, but the evidence will be used as the reference to do some action in order to prevent the same way accident. While, from the Law perspective probable cause terminology is used for the evidence by the legal enforcer to process the pilot and Air Traffic Control (ATC) staff by legality, for example the case of Garuda's accident in Yogyakarta in 2005 that finally bring

A. Hopkins, 2000, Lessons from Longford: the Esso Gas Plant Explosion, CCH Australia Limited, Sydney, p. 2.

J. Leplat, "Event Analysis and Responsibility in Complex Systems", in A. Hale, M. Wilpert and M. Freitag (Eds.), 1997, After the Event-from Accident to Organisational Learning, Oxford, Pergamon, p. 8.

T. Kletz, 2001, Learning from Accidents, Gulf Professional Publishing, Oxford, p. 35.

Annex 13 to the ICAO Standard (ICAO 2001)

L. Fenwick, "A World Without Probable Cause, Air Accident Digest". hhtp://www.airaccidentdigest.com/blog/, accessed on 1 December 2013. See also G. McKellar, “A World Without Probable Cause, Air Accident Digest”, Beyond Probable Cause, ALPA Annual Safety Forum, http://www.airaccidentdigest.com/blog/, accessed on 1 December 2013. 
the pilot Marwoto Komar into court. The same way is also occur in the Olympic Airline Falcon 900B (1999) case in Thessaloniki Yunani. ${ }^{24}$

The comprehensive approach is used by James Reason that views an accident as system accident. According to the Reason, aircraft accident is not isolated event but, it is a system failure that active or latent. Reason also explains that in conducting an investigation the investigator must applied an approach with the thing related to the aviation safety system by doing some research to the active and latent failure, also the steps of other system failure. Therefore, according to Reason:

[...] errors are seen as consequences and not as causes and the origin of error is not so much in human nature but in systematic factors that include recurrent error traps in the workplace and the organizational process giving rise to them. A serious shortfall of examining only the human factors in an investigation is that it isolates unsafe acts from their system context. ${ }^{25}$

From the explanation above, it can be concluded that the definition of cause or probable cause is an essential and the main purpose of aircraft accident investigation. The using of cause terminology shows the purpose of investigation is looking for the causes, so the main purpose is preventive in order to prevent the same way accident is occurring in the next day. The using cause terminology also indicates that the investigation is not for corrective which have a meaning if the facts from the investigation will be used as evidence to determine the fault party.

\section{Investigation Purpose}

Accident investigation has many purposes depend on the type of accident that is occurred. According to Mateou the aim of accident investigation such as: ${ }^{26}$ (i) identify and describe the course of the events (what, where, when), (ii) identify the direct causes and the contributing factors that led to the accident (why), (iii) identify measures to reduce the risk in order to prevent future similar accidents from occurring (learning), (iv) investigate and evaluate the basis for potential prosecution (blame), (v) evaluate the question of guilt in order to assess the liability for compensation (pay). According to the Hendrick and Benner the purpose of investigation must be reflecting three main characteristics that are: ${ }^{27}$ i) realistic, (ii) conducted in a non-causal framework resulting in an objective description of the events leading up to the accident, (iii) consistent. Meanwhile, based on the Stephen Dempsey there are three purpose of investigation such as: (i) to provide corrective action, (ii) to punish a wrongdoer, (iii) to compensate injured parties. ${ }^{28}$

The opinion from the three experts about accident investigation purpose can be concluded that the main purposes are to find out the accident cause, determine who is responsible, and determine the amount of compensation. Besides, according to the Annex 13 Chicago convention the main purpose of aircraft accident investigation is to prevent the similar accident in the future and not to find who are responsible for the accident. Specifically, Annex 13 state as follows: "The sole objective of the investigation of an accident or incident shall be the prevention of accidents and incidents. It is not the purpose of this activity to apportion blame or liability". The separation of investigation purpose is also confirmed in other part of Annex, as follow: "Any judicial or administrative proceedings to apportion blame or liability should be separate from any investigation conducted under the provision of this Annex". Therefore, this separation is popping up two types of investigation that are technical investigation and juridical investigation. Technical investigation is oriented to the research about the accident causes and the action to prevent it, while

\footnotetext{
Mateou and Mateou, Op.cit., p. 42.

J. Reason, "Human Error: Models and Management", British Medical Journal, Vol. 320, Issue 7237, 2000, pp. 768-70.

Mateou and Mateou, Op.cit., p. 31.

K. Hendrick and L. Benner, "Investigation Concepts", in Hendrick and Benner, 1986, Investigating Accidents with STEP, Marcel Dekker, New York, p. 40.

28 Dempsey, Op.cit., p. 231
} 
the juridical investigation is aimed for determine who are fault and responsible with the accident. ${ }^{29}$

Other things that need to be considered related to the investigation purpose are function and social role. In this case investigation is conducted to ensure the public if the investigation is conducted to find out the accident cause and to take a lesson in order to make the accident do not recur. ${ }^{30}$

As the comparison, regulation concerning aviation in United Kingdom is ruling about the purpose of investigation, as follows: "The sole objective of the investigation of an accident or incident under these Regulations shall be the prevention of accidents and incidents. It shall not be the purpose of such an investigation to apportion blame or liability". ${ }^{31}$ Meanwhile, in Australia, it states that: "The following are not objects of this Act: (a) apportioning blame for transport accidents or incidents; (b) providing the means to determine the liability of any person in respect of a transport accident or incident; (c) assisting in court proceedings between parties (except as expressly provided by this Act); (d) allowing any adverse inference to be drawn from the fact that a person is subject to an investigation under this Act". ${ }^{32}$

According to the explanation above, so the main purpose of aircraft accident investigation is to determine the causes (can be an action, process, event, conditions, or system failure) which cause an accident by evaluating the evidences and then make a conclusion that will be used as recommendation to prevent the same accident in the future. Related this thing, Dempsey said that: "It is the enhancement of safety and not the apportionment of blame that is the goal of the independent accident investigation". ${ }^{33}$

\section{Investigation Process}

The normal procedures of investigation are: (i) determining the scope and field of investigation, (ii) collecting evidences; (iii) selecting the evidences; (iv) analyzing the evidences and making recommendation; (v) making a report about the result of investigation; (vi) making a recommendation based on the investigation fact. Thus process is same with process investigation in the Annex 13, here are the investigation process that rule in the Annex 13: creating investigation team, collecting, recording, and analyzing the evidences that is relevant, determining the accident cause, formulating recommendation and preparing the report. ${ }^{34}$

Manual of Aircraft Accident Investigation: 2000 suggest for avoiding a premature conclusion and making sure that each investigation must be considering elimination technique that is based on the particular situation in which some fact that possible to be considered as possible cause can be eliminated in the beginning step. The consequence will make others facts need to be analyzing extensively and deeply. ${ }^{35}$

Data analyzing is the most difficult step in investigation accident, because there is limited guidance that is given by ICAO. The investigation report form that is given by ICAO is only contains about the writing style and no provide guidance about data analyzed. Therefore, it can be understood if aircraft accident investigation report usually makes a controversy and debate. ICAO is pressed to give clear guidance about data analyze.

The investigation purpose is to prevent the same way accident occur in the future, therefore in the final report investigation will be completed with some recommendations about aviation safety. This recommendation must be supported by some evidences that are gained from the investigation

\footnotetext{
Also see John A. Stoop \& James P. Kahan, "Flying is the Safest Way to Travel: How Aviation was a Pioneer in Independent Accident Investigation", European Journal of Transport and Infrastructure, Vol. 5, No. 2, 2005, pp. 115-117.

Dempsey, Op.cit., p. 233

See Article 4 of the Civil Aviation (Investigation of Air Accidents and Incidents) Regulations 1996 No. 2798

See Section 7.3 of the Australia Transport Safety Investigation Act 2003.

Dempsey, Op.cit., p. 233

Completely conatin as follow: "[...] the investigation consists of the gathering, recording, and analysing all available relevant information and, if possible, determining the causes (s) and completing the Final Report followed by, where appropriate, the making of safety recommendations".

35 Mateou and Mateou, Op.cit., p. 48
} 
process and other sources that are relevant. But, in the practice it is usual that the recommendations cannot be implemented entirely with some reason. ${ }^{36}$

\section{The Scope of Investigation}

Before the investigation is conducted, it is important to determine the scope of this investigation. In usual the scope of investigation will be determined by some factors such as investigator, time allocation, work responsibility, etc. In practice the investigator is finding some difficulties to determine the investigation scope. How long time that is needed? How about the procedure that will be use to start and end the investigation? What are the criteria to determine if the investigation was declared ended?

The most important thing to be considered by the investigator to determine the investigation scope is gained a safety benefit. Accident investigation agency in each country usually applies a policy if the investigation scope depends on the benefit safety that will be gained.

One of the most important question related with the investigation scope is all the accident that is classified into accident or incident must be conducted an investigation? The answer is yes. Moreover, it is depend on the level and quality of investigation. Usually investigation will be categorized a research into accident which are accident and incident. At least there are any two reasons that are used; first, considering the availability of investigator with the aim for making the investigation focuser to do analyze to the facts that was founded. Second is considering about the contribution of investigation to the improvement safety aviation. Both of the consideration is based on the criteria before the investigation is conducted such as: Is the accident including into accident or incident, how far the accident is affected to the public need, the type of plane, etc. ${ }^{37}$

\section{Independence of Investigation Agency}

Aircraft accident investigation usually is conducted by special agency that is formed by government for this purpose. In United States the agency that is responsible to do this role is National Transportation Safety Bureau (NTSB) and in Indonesia this role is taken by National committee of safety transportation (KNKT). The basic thing that must be needed by this agency is independence. It is very important because the recommendation result must be objectively, not directed to one of one interest party but to improve the aviation safety.

The credibility of this agency depends on some factors, such as: competence, integrity, neutrality, and independence. ${ }^{38}$ The credibility investigation agency is very important if recommendation that was given will be directed as a corrective action which is based on the objective facts in the investigation. Credibility and integrity an investigation agency is determined by independence, autonomy, and technical ability of the investigator so, they can give an objective action, impartial, free from the politic interest, and free from the conflict. ${ }^{39}$

Annex 13 explicitly is required all the investigation agency to be independence, "[...] the accident investigation authority shall have independence in the conduct of the investigation and have unrestricted authority over its conduct [...]". However, this independence does not have to mean that the investigation agency should not be a government agency. So, the independence is meaning as a manner and not in the institution meaning. The reasons are for accommodating the selected countries that have many limitations so it is not possible to have an independence agency that exclude from the government. In this case the ICAO as quoted Dempsey stated as follows:

A State's primary aviation legislation should contain provisions to enable the Government

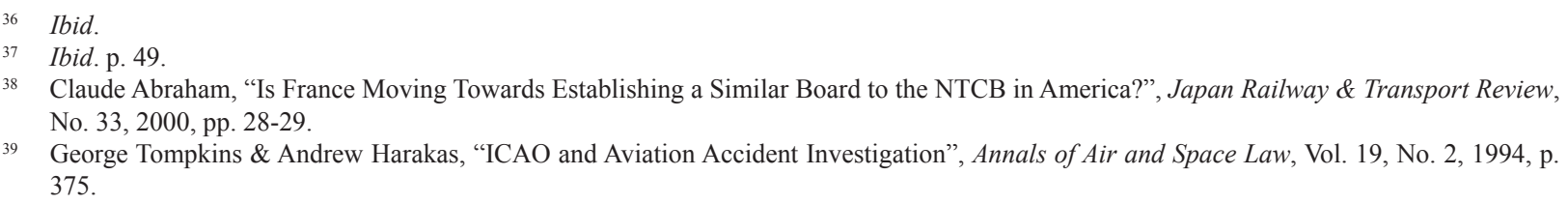

Claude Abraham, "Is France Moving Towards Establishing a Similar Board to the NTCB in America?", Japan Railway \& Transport Review, No. 33, 2000, pp. 28-29.

39 George Tompkins \& Andrew Harakas, "ICAO and Aviation Accident Investigation", Annals of Air and Space Law, Vol. 19, No. 2, 1994, p. 375. 
and its administration to conduct or participate in aircraft incident and accident investigations which may be vested in an independent or separate body [...] The State should establish an investigation authority to be responsiblefor the conduct of accident and incident investigations. ${ }^{40}$

Manual ICAO about the aircraft accident investigation is also stressed if the investigation agency should be really objective and impartial and always known like that. This agency need to keep distance with politic interest and not allowed to give up to the pressure and politic intervention. In the investigation of Adam air case in 2007, the investigation result of KNKT is negative responded from the public because it is indicated a politic intervention by the founder of Adam Air Agung Laksono at this time as the leader of DPR. To make sure the independence of investigation agency, Uni Eropa set up that the agency must be separated from government in financial, function and management aspect with others agencies that related to the airworthiness, certification, aviation management, plane maintenance, license, lighthouse, or others agencies that are related with duty and function investigation agency. ${ }^{41}$

To keep the independence of investigation agency that really consistent with the main function is finding cause or probable cause, Annex 13 recommended to others agencies not to interfere with accident investigation. ${ }^{42}$ Therefore, it is recommended to investigation agency to do coordination with other judicial institution in doing their duty while maintaining the independence. In general, the evidences that is gained from the investigation is secret, except if the court decided that this document must be opened because it will give certain effect for national and international or it is needed for the next investigation. ${ }^{43}$

\section{Aircraft Accident Investigation: Technical or Juridical?}

According to Sofia and Mateou, there are two types of investigation that is conducted related to the aircraft accidents that are technical investigation and juridical investigation. ${ }^{44}$ The main purpose of technical investigation is to prevent the same way accident in the future. ${ }^{45}$ So that, technical investigation is not directed to find who are responsible and not to find some evidences that will be used in the court. Technical investigation is non-punitive in nature. ${ }^{46}$ According to the Dempsey, the main purpose is to know the probable cause or causes of accident that the final result is to improve the quality of aviation safety. ${ }^{47}$

In the other hand, juridical investigation is conducted to determine who are guilty or responsible to the accident and then will be used as the recommendation to determine the amount of compensation. This investigation is using punitive approach that is focused from the facts and evidences which were collected during the investigation. Based on the Cortiz and Capaldo, this investigation is also conducted for responding the related party interest after the accident for example to determine the compensation for victim's family, public interest by determine the criminal doer, etc. ${ }^{48}$

The both of investigation are different so, the conflict and diversity is really possible to be happened. Technical investigation is preferred to look for the cause of accident which the out-put is recommendation that is given to repair the system

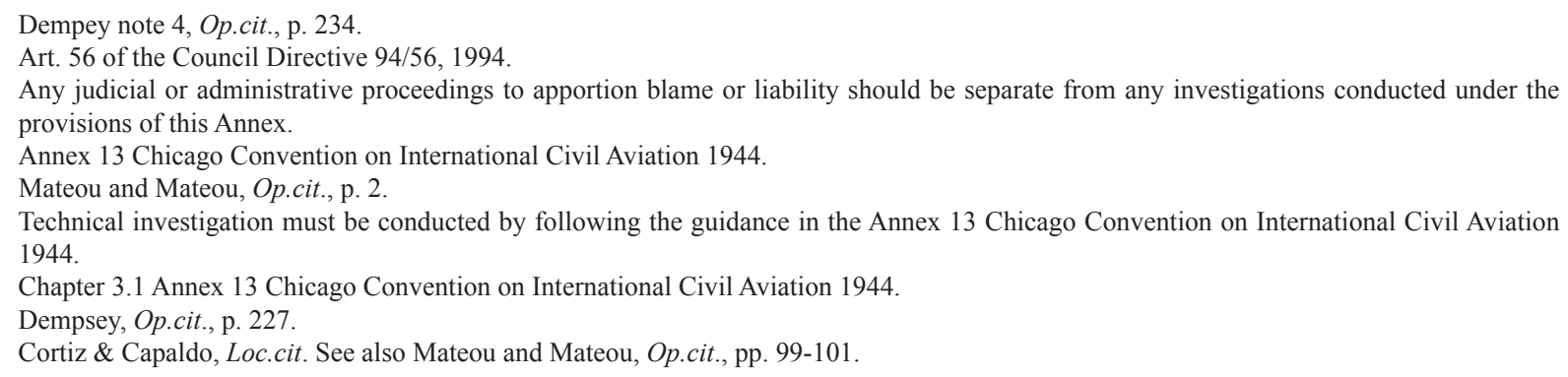


in order to prevent the same way accident in the future. While, juridical investigation is focused to the causes of accident that the result is to determine the guilty and responsible parties.

The question is How about the relation and interaction between the both of these investigations. In the Common Law countries such as United State, United Kingdom, and Australia the priority is given to the technical investigation, unless there is any criminal assumption like terrorism. In addition, in the Civil Law (Napoleonic Code) countries such as France, Italy and Netherland are giving the priority to the judicial authorities to conduct juridical investigation. ${ }^{49}$

The relations between these investigations are not always harmonic, the example in the crash case of Tranworld Airlines B747 Flight 800 in 1996 on Atlantic Ocean in the flight from New York to Paris. The report of NTSB concludes that the probable cause is explosion from the fuel tank. This report is following up by FBI (Federal bureau Investigation) as criminal investigation by interviewing thousands people included the witnesses. The interesting point is the senate of US state that the action of FBI is disturbing the investigation and risking for public safety. ${ }^{50}$

The example of cooperation between technical and juridical investigation is shown in the Pan-AM (1988) case that explode and fall in Lockerbie. In the report of Air Accident Investigation Board United Kingdom is reporting that the explode cause of Pan-Am plane is caused by explosive material. This report becomes indication that there is any criminal action (terrorism). After that, the investigation change into juridical investigation. ${ }^{51}$

In the common-law countries the aircraft accident investigation is giving priority to the technical investigation. Juridical investigation will be conducted if there is criminal indication that is reported by technical investigation. It is mean that juridical investigation is a sequel investigation from technical investigation so, it is not independence investigation but rely on the result of technical investigation. $^{52}$

According to the agreement between the Crown Prosecution Service (CPS) and Air Accident Investigation (AAIB) the main purpose of aircraft accident investigation in England is used for preventing the same accidents in the future and not to apportion blame or liability. ${ }^{53}$ The authority of AAIB is ruled in the article 9 (10) the Civil Aviation Act 1982, as follows:

Free access to the acident site; the aircarft, its contents or its wreckage; witnesses; the content of flight recorders; the result of examination of bodies; the results of examinations or tests made on sample from persons involved in the aircraft's operation and relevant information or records. They also have the power to control the removal of debris or components; examine all persons as they think fit;take statements; enter any place, building or aircraft; remove and test components as necessary and take measures for the preservation of evidence.

Data and information that is gained by AAIB is very secret and not allowed to be distributed to the others agencies include police and CPS. However, if CPS find a criminal indication based on the report of AAIB, CPS will tell to AAIB and it agency need to give final report to the CPS, and this report is secret. ${ }^{54}$ If someday the investigation is founded a strong criminal indication, so the investigation will be juridical investigation like the Pan Am case that fall in Lockerbie in 1988.

Mateou and Mateou, Ibid.

50 NTSB, “Aircraft Accident Report: In-flight Breakup over the Atlantic Ocean Trans World Airlines Flight 800”, 2003, NTSB Number AAR00/03; NTIS Number PB2000-910403.

51 See Sofia Michaelides, "The Lockerbie Trial: The End of A Chapter - Not The End of A Chapter", Paper, presented at the Cine Studio, University of Nicosia, Siprus, 2001.

Mateou and Mateou, Op.cit., p. 102.

53 AAIB, "Memorandum of understanding between the Crown Prosecution Service and the Air Accidents, Marine Accidents and Rail Accidents Investigation Branch".

54 Ibid. 
In America, the investigation of aircraft accident is conducted by NTSB, but if there is any strong indications of criminal thing the law enforcer will be conducting an investigation parallel with NTSB. It can be seen at the case of Alaska Airlines MD-83 Flight 261. ${ }^{55}$

On 31 January 2000, MD-83 Alaska Airline Inc. Flight 261 fly from Puerto Vallarta Mexico to Seatle by transit in San Francisco California, the air plane fall at Pacific Ocean. Pilot, co-pilot, three crews, and 83 (eighty three) passengers were killed. The plane is wreck. Following up the accident, FBI conduct an investigation because it is guessed a criminal indication and negligence operational by the Airlines. However, the VBI's investigation is suspended because NTSB concluded that the probable cause of this accident is effect of lubrication deficiencies on the aircraft mechanical systems. ${ }^{56}$

Meanwhile, in the civil law countries the role of juridical investigation is more prominent that technical investigation. ${ }^{57}$ In Italy, France, and Netherland included Russia the law enforcer is allowed to conduct juridical investigation and take the main role in the aircraft accident investigation especially in the investigation of data in the Cockpit Voice Recorder (CVR) and Flight Data Recorder (CDR). This mechanism is usually creating a tension between law enforcer institution and technique investigation agency, the example is the fall of BAC 1-11 Air plane in Italy. BAC 1-11 is the plane English registered that fall near Milan on January $4^{\text {th }} 1969$. In this case the institution of law enforcer Italy is not allowed England investigation agency to bring the FDR in order to be processed and read in England. The problem is when the Italy law enforcer institution cannot read the data of this FDR. Investigation agency of England states that the data of FDR is needed to prevent the same accident. Finally, Italy agrees to bring the FDR to be read in England.
In Netherlands can be seen in the fall of Turkish Airline at Schipol Airport. On 25 February 2009 Boeing 373-800 owned by Turkish Airline is fallen after some minutes take off from Schipol Airport. The air plane split into three parts and killed 128 passengers, 3 crews, and injured 50 passengers. The investigation is conducted by the Dutch Safety Board (DSB) or Onderzoekstraat voor Veligheid $(O V V)$ and in the same time it is conducted a juridical investigation by law enforcer institution. The FDR and CVR are founded by technique investigator and then sent to France to be processed. Law enforcers ask to the DSB to give the FDR and CVR, but it is refused. This situation makes a strained situation between these institutions. Finally, Boeing and Airbus is announcing that the cause of accident is caused by malfunction of radio altimeter. ${ }^{58}$

In Russia juridical investigation is usual conducted after aircraft accidents occur. It can be seen from the case of Challenger 850 on 13 February 2007. The airplane departure from Moskow to Vnukovo after that go to Berlin, the airplane fall after failure in take off. Fortunately, this plane only carries pilot and three cabin crews.

\section{Aircraft Accident Investigation System in Indonesia}

In Indonesia should follow the aircraft accident investigation system like in Netherland, because Indonesia is known as a country that closes to civil law tradition. However, the Law Number 1 of 2009 seems to exclude Indonesia as country with civil law tradition. Article 357 Law No. 1 of 2009 implicitly confirms that Indonesia has a priority I technical investigation, states that:

a. Government is conducting advance investigation and research about the accident cause and serious accident with civil aircraft that is occurred in the Republic of Indonesia area.

b. The execution of advance investigation and research as mention in the article

\footnotetext{
Mateou and Mateou, Op.cit., pp. 104-105.

J. White, "The Alaska Airlines Crash: Signs Point to a Wider Crisis in Air Safety", as quoted by Mateou and Mateou, Ibid.

L. Fenwick and M. Huhn, "Criminal Liability and Aircraft Accident Investigation", Air Line Pilot, May 2003, p. 17.

Mateou and Mateou, Op.cit., pp. 115-116.
} 
1 is conducted by national committee that is formed and responsible to the president.

Therefore, juridical investigation is conducted after technical investigation if there is any criminal indication in this aircraft accident. In the other word, Indonesia is not using priority of juridical or parallel investigation between technical and juridical. This case is explicitly can be understood from the rule of Article 359 Law No. 1 of 2009 that contains as follow: "The result of investigation cannot use for evidences in the judicial process". It's mean that investigation for judicial process is conducted separately with technical investigation, because the data and information from technical investigation is only directed to repair the safety system not to determine who are guilty or responsible to the accident.

This provision seems to be inspired to the crash of Garuda Boeing 737-400 in Adisucipto Airport of Yogyakarta on 7 March 2007. The investigation result from KNKT state that the accident occurs because the pilot is landed the airplane in high speed condition, so the airplane split into two parts and burned. After that, juridical investigation is conducted to the Pilot Captain Marwoto Komar with the "negligence" accusation that make dozens passengers were killed. This action makes a controversial case because it is indicated that any "criminalization" to the pilot that should be prosecuted through the enforcement of professional ethics forum.

Reflected from this event it seems that the legislators are not want a criminalization to pilot.
Therefore, this regulation creates a Profession Assembly Flight. This case is ruled in Article 364 that contain as below:

To conduct advance investigation, establishment of ethic profession, conduct mediation, and interpret the regulation the national committee create a Profession Assembly Flight.

This action is indicated that Indonesia want to place the malpractice possible that is done by pilot into ethic profession case and not directly guess as criminal action.

\section{Conclusion}

The main purpose of aircraft accident investigation is to find the factors that become cause or probable cause for the accident. These factors will be used as the recommendation to improve the aviation safety system in order to prevent the same accident in the future. The purpose of aircraft accident investigation has technical characteristic. Furthermore, it is possible to conduct an investigation with juridical purpose if there is any criminal indication and law violation. Technical and juridical investigation can run proportionately if the juridical investigation is conducted as advance investigation. It is better for Indonesia to follow the recommendation from ICAO in conducting aircraft accident investigation that is placing the investigation as technical investigation. Law provision regarding aviation in Indonesia has followed the rule of ICAO regarding the aircraft accident investigation and it is a right way, because it will avoid from the criminalization action to the involved parties that are not guilty.

\section{BIBLIOGRAPHY}

\section{A. Books}

Dempsey, Paul Stephen, 2008, Public International Law, McGill University, Canada.

Hopkins, A, 2000, Lessons from Longford: the Esso Gas Plant Explosion, CCH Australia Limited, Sydney.

Kletz, T., 2001, Learning from Accidents, Gulf
Professional Publishing, Oxford.

Lesley Brown, 1993, The New Shorter Oxford English Dictionary, 1993, Clarendon Press, Oxford.

Mateou, Michaelides and Andreas Mateou, 2010, Flying in the Face of Criminalization: The Safety Implications of Prosecuting Aviation 
Professionals for Accidents, Ashgate, UK.

Tench, W.W., 1985, Safety is No Accident, Collins and Professionals and Technical Books, London.

Wells, Alexander T., and Clarence C. Rodrigues, 2003, Commercial Aviation Safety, New York, McGraw-Hill.

\section{B. Anthologies}

Hendrick K., and L. Benner, "Investigation Concepts", in Hendrick and Benner, 1986, Investigating Accidents with STEP. Marcel Dekker, New York.

Leplat, J, "Event Analysis and Responsibility in Complex Systems", in A. Hale, M. Wilpert and M. Freitag (Eds.), 1997, After the Event - from Accident to Organisational Learning, Pergamon, Oxford.

\section{Journal Articles}

Abraham, Claude, "Is France Moving Towards Establishing a Similar Board to the NTCB in America?", Japan Railway \& Transport Review, No. 33, 2000.

Cortiz, Col. Luis E \& Griselda Capaldo,"Can Justice Use Technical and Personal Information Obtained Through Aircraft Accident Investigations?", Journal of Air Law and Commerce, Vol. 65, No. 2, 2000.

Dempsey, Paul Stephen, "Independence of Aviation safety Investigation Authorities: Keeping the Foxes from the Henhouse", Journal of Air Law and Commerce, Vol. 75, No. 2, 2010.

Huang, Jiefang "Aviation Safety, ICAO and Obligation Erga Omnes", Chinese Journal of International Law, Vol. 8, No.1, 2009.

Kjellen, U and T.J. Larsson, "Investigating Accidents and Reducing Risks - A Dynamic Approach", Journal of Occupational Accidents, Vol. 3, 1981.

Miller, C.O, "State of the Art in Air Safety", Journal of Air Law and Commerce, Vol. 34, 1957.
Reason, J. "Human Error: Models and Management", British Medical Journal, Vol. 320, Issue 7237, 2000.

Shubert, Francis,"Legal Barriers to a Safety Culture in Aviation", Annals of Air and Space Law, Vol. 29, Issue 1, 2004.

Stoop, John A \& James P. Kahan, "Flying Is the Safest Way to Travel: How Aviation Was a Pioneer in Independent Accident Investigation" European Journal of Transportation and Infrastructure, Vol. 5, 2005.

Tompkins, George \& Andrew Harakas, "ICAO and Aviation Accident Investigation", Annals of Air and Space Law, Vol. 19, No. 2, 1994.

Wassenbergh, H, "Safety in Air Transportation and Market Entry", Journal of Air and Space Law, Vol. 23, No. 2, 1998.

\section{Papper}

Michaelides, Sofia, "The Lockerbie Trial: The End of A Chapter - Not The End of A Chapter", Papper, presented at the Cine Studio, University of Nicosia, Siprus, 2000.

\section{E. Government Regulations}

Law Number 21 of 2013 on Outer Space (State Gazette of the Republic of Indonesia Year 2013 Number 133, Supplement to State Gazette of the Republic of Indonesia Number 5435).

Law Number 1 of 2009 on Aviation (State Gazette of the Republic of Indonesia Year 2009 Number, Supplement to State Gazette of the Republic of Indonesia Number 4956).

\section{F. International Convention}

The Australia Transport Safety Investigation Act 2003. The UK Civil Aviation (Investigation of Air Accidents and Incidents) Regulations Number 2798 Year 1996.

Chicago Convention on International Civil Aviation 1944. 